\title{
Membangun Nilai Kompetitif Perguruan Tinggi sebagai Organisasi Pembelajaran dalam Perspektif Tatanan Mikro, Makro dan Lingkungan Eksternal
}

\author{
Marselinus Heriteluna \\ mheriteluna@yahoo.com/hari3luna@gmail.com
}

\begin{abstract}
Abstrak
Perguruan Tinggi (PT) sebagai organisasi pembelajaran diharapkan menjadi sebuah organisasi motor penggerak perubahan dalam perbaikan kualitas pendidikan di Indonesia. Peran PT dalam pendidikan merupakan usaha atau proses yang ditujukan untuk membina kualitas sumber daya manusia seutuhnya agar ia dapat melakukan perannya dalam kehidupan secara fungsional dan optimal. Dengan demikian sesuai hakikat pendidikan, PT pada intinya menolong di tengah-tengah kehidupan manusia dan dapat dirasakan manfaatnya bagi manusia.Melalui implementasi pada tatanan mikro, makro dan Lingkungan Eksternal, PT dapat melakukan berbagai langkah operasional. Artikel ini bertujuan membahas beberapa langkah strategis yang dapat dilakukan Perguruan Tinggi, dalam kaitannya sebagai Organisasi Pembelajaran.
\end{abstract}

Kata Kunci:organisasi pembelajaran, perguruan tinggi, tatanan makro, mikro dan lingkungan eksternal

\begin{abstract}
Higher Education (HE) as a learning organization is expected to become anorganization changes a driving force in improving the quality of education inIndonesia. The role of $\mathrm{HE}$ in education is a business or a process aimed at fostering the quality of human resources fully so that it can perform its role in life, functionally and optimally. Thus according to the nature of education, HE in essence help in the midst of human life and can be perceived benefits for humans. In order of micro, macro and External Environment, HE can perform a variety of operational steps. This article aims to discuss some strategic steps that can be done, in relation to the Learning Organization.
\end{abstract}

Keywords: learning organizations, universities, the order ofmacro, micro and external environment

\section{PENDAHULUAN}

Perguruan Tinggi (PT) di Indonesia berperan sebagai lembaga pelaksana pendidikan dan pengajaran, penelitian, dan pengabdian kepada masyarakat, yang disebut dengan Tri Dharma Perguruan Tinggi (PP No.60 tahun 1999). PT sebagai lembaga pendidikan dan pengajaran, berfungsi menyiapkan lulusan yang terdidik, memiliki kemampuan akademik dan kemampuan profesional. PT sebagai lembaga penelitianberperan melaksanakan berbagai kegiatan penelitian sebagai upaya dalam memecahkan permasalahan yang berkenaan dengan suatu bidang ilmu pengetahuan dan teknologi secara ilmiah, dan melakukan berbagai upaya pengembangan yang bermanfaat bagi pembangunan. PT sebagai lembaga pengabdian kepada masyarakat, berperan melakukan berbagai kegiatan 
sebagai upaya dalam memotivasi, berpartisipasi dan menunjang pembangunan masyarakat melalui pemanfaatan secara nyata baik ilmu pengetahuan maupun teknologi.

Peran perguruan tinggi yang tidak kalah penting selaian sebagai lembaga pendidikan pengemban Tri Dharma, adalah sebagai lembaga yang menghasilkan calon pemimpin bangsa yang bermoral dan berbudaya demokratis. Jika perguruan tinggi terlalu terjebak dalam arus globalisasi yang merupakan suatu proses yang nirdemokratis, secara pasti perguruan tinggi tidak akan mampu melaksanakan salah satu tugas utamanya tersebut (Efendi, 2003).

Peran dan fungsi PT sebagaimana telah dikemukakan tersebut menjadikannyasebagai organisasi yang mewadahi dan lembaga strategis dalam membangun komponen bangsa dan negara (Indonesia). Di era Globalisasi seperti saat sekarang ini, PT sebagai organisasi ilmiah dan akademik yang menyelenggarakan pendidikan dan pengajaran, dituntut untuk meningkatkan kualitasnya secara terus menerus. Hal tersebut disebabkan oleh kualitas SDM Indonesia yang masih tergolong rendah dengan predikat negara berkembang pada tingkat menengah.

United Nations Development Programme(UNDP) mencatat bahwa kualitas SDMIndonesia masih berada pada urutan diatas 100.Pada tahun 2005 Indonesia menempati urutan 110 dari 117 negara dengan indeks 0,697. Urutan tersebut mengalami penurunan dari tahun 1999 yang menempati posisi 102 dengan indeks 0.677 . Posisi tersebut masih berada di bawah negara tetangga seperti Malaysia (urutan 61/0.796), Thailand (73/0.778), Filipina (84/0.758) dan Vietnam (108/0.704). Data terbaru dari Laporan United Nations
Development Program tahun 2013, IPM Indonesia berada di urutan 108 dari 187 negara yang disurvei, dengan skor 0,684. Hal ini cukup menggembirakan karena urutan ini meningkat dari peringkat 124 pada tahun 2012, namun posisi ini tidak bergeser di kawasan ASEAN, yaitu posisi kelima. Peringkat pertama IPM di tingkat ASEAN tahun 2013 adalah Singapura dengan nilai IPM 0,921 (9), dan disusul Brunei dengan IPM0,852 (30), Malaysia dengan IPM 0,773 (62), dan Thailand dengan IPM 0,722 (89). Indonesia hanya unggul dari Filipina dengan IPM 0,660 (117), Vietnam dengan IPM 0,638 (121), Kambodja dengan IPM 0,584 (138), Laos dengan IPM 0,669 (139), dan Myanmar dengan IPM 0,524 (150).

Berdasarkan pengukuran indikator IPM Indonesia pada tahun 2014, angka harapanhidup 68,9 tahun, harapan tahun bersekolah 13, serta rata-rata waktu sekolah yangdijalani individu berusia 25 tahun ke atas adalah 7,6 tahun. Pendapatan nasional brutoper kapita 9.788 dollar AS (setara Rp 137,5 juta dengan nilai tukar Rp 14.048).Ada peningkatan IPM Indonesia sekitar 44,3 persen dengan membandingkan IPM tahun1990 yang besarannya 0,474 menjadi 0,684 pada 2013.

Gambaran IPM tersebut juga sejalan dengan kemampuan daya saing SDM Indonesia di tingkat global. The Global Competitiveness Report 2015-2016 yang dikeluarkan World Economic Forum(WEF), sebagaimana dilansirBloomberg pada hari Rabu tanggal 30 September 2015,menunjukkan peringkat daya saing SDM Indonesia juga mengalami peningkatan dari posisi 46 pada tahun 2012 menjadi 37 pada tahun 2015. Mantja (2010) mencatat setidaknya 3 perubahan besar di era globalisasi yang di jalani oleh bangsa Indonesia. Pertama,adanya pergeseran nilai 
karena perubahan struktur yang terjadi pada bangsa Indonesia. Kedua, perubahan nilai yang terjadi karena pembangunan. Ketiga, perubahan nilai yang terjadi tidak sengaja karena transfer teknologi melalui pembangunan.Namun demikian, posisi daya saing Indonesia masih terendah di negara pendiri ASEAN (Singapura rangking 5, Malaysia 21, Thailand 34).

Masih rendahnya kualitas SDM di Indonesia menjadi tugas berat bangsa, dalam hal ini adalah lembaga pendidikan, praktisi dan ahli-ahli pendidikan, serta masyarakat. Perguruan Tinggi adalah bagian intergral dari Sistem Pendidikan Nasional yang memegang peranan strategis pada garda terdepan dalam upaya-upaya pengentasan masalah kualitas SDM melalui jalur pendidikan. Berkenaan dengan itu, pembahasan dalam artikel ini lebih difokuskan padapengkajian Perguruan Tinggi sebagai organisasipembelajaran yang berperan membangun nilai kompetitif dalam perspektif tatanan mikro, makro, dan lingkungan eksternal di Indonesia.

\section{Organisasi Perguruan Tinggi}

Pendidikan adalah sebuah upaya sadar dan terencana untuk mewujudkan suasana belajar dan proses pembelajaran agar peserta didik secara aktif mengembangkan potensi dirinya untuk memiliki kekuatan spiritual keagamaan, pengendalian diri, kepribadian, kecerdasan, akhlak mulia, serta ketrampilan yang diperlukan dirinya, masyarakat, bangsa dan negara (UU No.20 Tahun 2003 tentang Sisdiknas Bab I Pasal 1 Ayat 1). Hal ini termaktub di dalam Renstra Depdiknas 2005 - 2025, yaitu mewujudkan pendidikan yang mampu membangun insan Indonesia cerdas dan kompetitif, yang berkeadilan, bermutu $\mathrm{dn}$ relevan dengan kebutuhan masyarakat lokal dan global.

Pendidikan adalah salah satu pilar yang mendukung keberlangsungan kehidupan berbangsa dan bernegara. Tidak dapat disangkal bahwa pendidikan berfungsi untuk mengembangkan potensi peserta didik, agar terwujud manusia yang bertanggung jawab terhadap kehidupan bangsa dan masyarakat yang ditandai dengan karakteristik manusia Indonesia (UU No.20 tahun 2003). Dalam proses pencapaian target Renstra pendidikan tersebut, bangas ini menghadapai berbagai permasalahan berkaitan kualitas pendidikan yang masih rendah, untuk kawasan Asia, bahkan dunia. Untuk tingkat satuan pendidikan, Sallis (1993) menyebutkan rendahnya mutu pendidikan adalah dapat disebabkanoleh bermacam sumber: ketidak sesuaian perancangan kurikulum, ketidakcocokan pengelolaan gedung, lingkungan kerja (iklim organisasi), yang tidak kondusif, ketidaksesuaian sistem dan prosedur (manajemen), tidak cukup jam pelajaran, kurangnya sumber daya, dan pengembangan staf. Hal ini dikarenakan kemampuan para pengelola yang kurang profesional dalam mengelola organisasi pendidikan.

Organisasi adalah suatu kelompok orang dalam suatu wadah untuk tujuan bersama.Barnard (1992) mendefinisikan An organization as a system of cooperative activities of two or more persons. SementaraJames D. Oony mendefinisikan Organization is the form of every human association for the attainment of comon purpose (dalam Wahab, 2006). Definisi tersebut menunjukkan bahwa organisasi adalah sebuah bentuk atau sistem yang terdiri dari sekelompok manusia yang 
berkerjasama untuk mencapai tujuan bersama.

Oganisasi memiliki pimpinan dengan sebutan tertentu dan setiap unit kerja yang ada di dalamnya juga dipimpin oleh seorang kepala/pimpinan yang menduduki posisi menurut tingkat unit kerjanya di dalam keseluruhan organisasi. Posisi, tanggung jawab dan wewenang di dalam suatu kelompok formal terikat pada struktur dan dibatasi oleh peraturan-peraturan yang mendasari pembentukan organisasi kerja tersebut. Hubungan kerja yang didasari wewenang dan tanggung jawab, baik secara vertikal maupun horizontal dan diagonal akan menunjukan pola tertentu sebagai mekanisme kerja. Salah satu bentuk organisasi yang dikenal adalah perguruan tinggiyang disebut sebagai organisasi pendidikan (organisasi pendidikan mikro), karena didirikanuntuk mencapai tujuan bersama khususnya dibidang pendidikan.

Sudah menjadi sesuatu yang sifatnya taken for granted bahwa secara struktur, manajemen organisasi pendidikan yang disebut perguruan tinggi (baik negeri maupun swasta) ditata dengan pola seorang rektor, ketua, atau direktur yang dibantu (pada lapis berikutnya) oleh (umumnya) wakil rektor, direktur atau ketua, yang masingmasing(secara berturut turut) membidangi akademik, keuangan dan administrasi umum, kemahasiswaan, atau yang lainnya. Desain ini dikembangkan terus ke bawah. Baik dalam konteks sebuah fakultas (Dekan, wakil Dekan I,II, dan III).

Disaat kompetisi antar organisasi perguruan tinggi saat ini yang berlangsung sangat ketat, persoalan produktivitas menjadi salah satu penentu keberlangsungan organisasi disamping persoalan kualitas dan kemampuan SDM yang terlibat di dalamnya. Jika memperhatikan filosofi struktur organisasi maka sebuah struktur lazimnya dibangun sebagai upaya distribusi beban kerja, untuk pada gilirannya diharapkan terjadi optirnalisasi tujuan organisasi. Dalam konteks organisasi bisnis (baca: komersial), secara konvensional dibagilah peran manajemen atas dasar fungsi-fungsi fimdamental perusahaan. Misalnya terdapat departemen atau bagian pemasaran, produksi atau operasi, keuangan, sumber daya manusia dan lainnya. Semua departemen atau bagian itu bekeja secara sinergis untuk mencapai, misalnya, laba optimal yang ditargetkan.

Permasalahannya,

mampukah organisasi PT dengan strukturnya tersebut dapat membangun distribusi beban kerja yang pada gilirannyamampu mengoptirnalisasikanpencapaian

tujuan organisasi. Tri Dharma Perguruan Tinggi yang menjadi tugas pokok PT yang terdiri dari pendidikan dan pengajaran, penelitian, dan pengabdian kepada masyarakat, umumnya menjadi bidang wakil rektor/ketua/direktur bidang akademik (wakil rektor/ketua/ direktur I). Sementara dua pembantu/wakil lainnya membidangi administrasi umum dan keuangan (pembantu/wakil rektor/ketua/ direktur II), dan kemahasiswaan (pembantu/wakil rektor/ketua/ direktur III).

$$
\text { Struktur organisasi }
$$

PTsemestinya dibangun sebagai upaya distribusi beban kerja untuk mengemban tupoksinya, sehingga pada gilirannya diharapkan terjadi optirnalisasi tujuan organisasi,yaitu Tri Dharma Perguruan Tinggi.Struktur organisasi PT yang umumnya ada saat ini menjadikan bidang penelitian dan pengabdian kepada masyarakat tidak seoptimal bidang pendidikan dan pengajaran. Hal ini mungkin menjadi salah satu penyebab rendahnya kualitas 
publikasi ilmiah yang dihasilkan PT. Berkenaan dengan itu, sejumlah PT telah menata struktur organisasinya sesuai dengan distribusi kerja sebagai usaha untuk mengoptimalkan pencapaian Tri Dharma Perguruan Tinggi. Struktur organisasi Universitas Indonesia, Rektor dibantu oleh empat orang wakil, yaitu: Wakil Rektor Bidang Akademik dan Kemahasiswaan, Wakil Rektor Bidang Perencanaan Keuangan dan Fasilitas, Wakil Rektor Bidang Riset dan Inovasi, dan Wakil Rektor Bidang SDM, Pengembangan dan Kerjasama. Struktur organisasi Universitas Gadjah Mada, Rektor dibantu oleh lima orang wakil rektor, yaitu: Wakil Rektor Bidang Akademik dan Kemahasiswaan, Wakil Rektor Bidang Perencanaan, Keuangan dan Sistem Informasi, Wakil Rektor Bidang Penelitian dan Pengabdian kepada Masyarakat, Wakil Rektor Bidang Sumber Daya Manusiadan Aset, dan Wakil Rektor Bidang Kerjasamadan Alumni.

Pengembangan struktur organisasi PT tersebut menunjukkan usaha yang dilakukan perguruan tinggi bersangkutan dalam rangka optirnalisasi

tujuan organisasinya,yaitu Tri Dharma Perguruan Tinggi. Usaha tersebut menunjukkan peningkatan kualitas pada bidang penelitian dan pengabdian kepada masyarakat.

\section{Perguruan Tinggi sebagai Organisasi Pembelajaran}

Kesuksesan sebuah organisasi pada era globalisasi sangat tergantung pada kemampuan organisasi tersebut untuk belajar dan merespon perubahan-perubahan yang terjadi dengan cepat.Untuk berkiprah dalam arus globalisasi, maka langkah yang harus dilakukan bangsa Indonesia adalah menata SDM, baik dari aspek intelektual, emosional, spiritual, kreativitas, moral maupun tanggung jawabnya.
Pendidikan mempunyai keterkaitan erat dengan globalisasi. Pendidikan tidak mungkin menisbikan proses globalisasi yang akan mewujudkan masayarakat global. Dalam era globalisasi, Indonesia harus melakukan reformasi dalam proses pendidikan dengan menciptakan sistem pendidikan yang lebih komprehensif dan fleksibe, sehingga produk pendidikan dapat berfungsi secara efektip dalam kehidupan masyarakat global yang demokratis.

Mantja, 2010 menyatakan setidaknya diera Indonesia baru, pendidikan nasional setidaknya menghadapi 4 tantangan besar yang kompleks, yaitu: pertama, tantangan untuk meningkatkan nilai tambah (added value) dalam rangka meningkatkan produktivitas nasional, pertumbuhan, dan pemerataan ekonomi, sebagai upaya untuk memelihara dan meningkatkan pembangunan berkelanjutan. Kedua, tantangan untuk melakukan kajian komprehensif dan mendalam terhadap terjadinya transformasi (perubahan) struktur masyarakat, dari masyarakat modern, menuju masyarakat industri yang menguasai teknologi dan informasi, yang implikasinya pada tuntutan dan pengembangan SDM (Sumber Daya Manusia). Ketiga, tantangan dalam persaingan global yang semakin ketat, yaitu meningkatkan daya saing bangsa dalam menghasilkan karya-karya yang bermutu dan mampu bersaing sebagai hasil penguasaan, pengetahuan, teknologi, dan seni (IPTEKS). Keempat, munculnya kolonialisme bari dibidang iptek dan ekonomi menggantikan kolonialisme politik. Dengan demikian kolonialisme sekarang ini bukan lagi dalam bentuk fisik akan tetapi berbentuk informasi, dalam bentuk perkembangan teknologi komputer dan internet, sehingga bangsa ini menjadisangat tergantung kepada bangsa barat dalam teknologi dan 
informasi. Hal ini telah menjadikannya Virtual enemy yang telah merasuk keseluruh pelosok dunia ini, sehingga wujud masyarakat yang diinginkan adalah yang berpendidikan (educated society). Berkenaan dengan itu, dunia pendidikan juga menghadapi reformasi kelembagaan/organisasi secara total untuk melaksanakan peran, fungsi. dan misinya secara optimal.

Pembaharuan-pembaharuan yang dilakukan perguruan tinggi adalah memfokuskan pada pelaksanaan visi dan misi dari perguruan tinggi. Pelaksanaan visi dan misi perguruan tinggi tersebut dapat diaplikasikan pada kebijakan otonomi perguruan tinggi dengan mengembangkan kurikulum yang ada agar lembaga pendidikan tinggi berkompetisi secara kualitas. Perguruan Tinggi juga mengemban tugas pokok, yaitu di satu fihak dituntut untuk mendidik para putera bangsa agar menguasai ilmu pengetahuan dan teknologi yang termutahir, yang mengharuskan setiap perguruan tinggi untuk selalu mempersiapkan tenaga kependidikan yang terbaik serta fasilitas pendukung yang tercanggih. $\mathrm{Di}$ lain fihak, dalam konteks Indonesia, PT juga memiliki kewajiban sosial yang tidak kalah pentingnya, yakni menjadi lokomotif pembangunan daerah dan nasional, termasuk mempersiapkan anak didik untuk menjadi calon-calon pimpinan bangsa yang bermoral tinggi serta berbudaya demokratis (Effendi, 2003)

Perguruan Tinggimerupakan salah satu organisasi yang harus merespon berbagai perubahan dunia di era glabilisasi ini. PT harus memiliki kemampuan untuk mengelola organisasi dengan berbasis ilmu pengetahuan, dan melakukan perubahan-perubahan yang diperlukan. Disinilah letak pentingnya organisasi pembelajar yang akan mengembangkan kapasitas organisasi untuk terus belajar, beradaptasi, dan berubah sejalan dengan perubahan disekitarnya. Peter Senge mengemukakan pengertian organisasi belajar adalah organisasi yang secara terus-menerus mengembangkan kemampuannya untuk menciptakan masa depan yang lebih baik. "Organisasi di mana orang-orangnya secara terusmenerus mengembangkan kapasitasnya guna menciptakan hasil yang benar-benar mereka inginkan, di mana pola-pola berpikir baru dan berkembang dipupuk, di mana aspirasi kelompok diberi kebebasan, dan di mana orangorang secara terus-menerus belajar mempelajari (learning to learn) sesuatu secara bersama".Ada beberapa faktor yang sangat berperan dalam mendukung terwujudnya organisasi belajar, antara lain: penguasaan individu, pembelajaran dalam kelompok, visi bersama, budaya pembelajaran dalam organisasi dan struktur dan sistem yang mendukung.

Organisasi pembelajaran

menurut Marquardt (1996,21) merupakan organisasi yang secara sungguh-sungguh dansecara kolektif melakukan proses pembelajaran, dan merubah dirinya dengan mengumpulkan,mengelola dan menggunakan pengetahuannya sebaik-baiknya untukkesuksesan organisasi, yang terdapat dalam system learning organizationmodel yang mencakup learning, organizaton, knowledge, technology, danpeople. Dikatakan selanjutnya bahwa Subsistem learning mengacu pada aspek level pembelajaran, tipepembelajaran yang krusial dalam organisasi pembelajar, dan skillpembelajaran. Pada aspek skill dalam learning organization, Senge (1996) menyebutkan terdapat cara berpikir yang sistematik (system 
thinking);kematangan pribadi (personal mastery); membangun model mental (mentalmodel); visi bersama (shared vision); dan pembelajaran tim (tim learning).

Pembelajaran organisasi menurutRedding (dalamMarquadt, 1996) dipengaruhi beberapa dimensi antara lain: (1)Speed of learning (kecepatan belajar), mengacu pada bagaimanaorganisasi mampu menjalani putaran siklus pembelajaran

(planning,implementing,

and reflecting) secara lengkap. (2)Depth of learning (kedalaman belajar), mengacu pada tingkatanorganisasi untuk mampu belajar pada akhir setiap siklusdengan pertanyaan asumsi-asumsi mendasar dan peningkatankapasitas untuk belajar menghadapi masa depan. (3)Breadth of learning (keleluasaan belajar), tentang bagaimanaorganisasi secara ekstensif mampu untuk mentransfer wawasan danpengetahuan baru yang diturunkan dari setiap sikluspembelajaran terhadap isu-isu baru dan terhadap bagianbagianorganisasi.

\section{Membangun Nilai kompetitif dalam berbagai tatanan Perguruan Tinggi}

Pandangan makro organisasi berfokus pada unit analisis yang lebih luas, khususnya dalam keseluruhan organisasi sebagai suatu unit (struktur, orang sebagai satu kelompok, teknologi, dan lingkungan).Sementara aspek mikro organisasi umumnya adalah difokuskan pada masalah-masalah dan isu-isu yang dihadapi oleh perseorangan/individual dan kelompok atau grup kecil di dalam sebuah organisasi (Daft L.R and Steers.M.R.1986: 5) yang difokuskan pada kepemimpinan, motivasi dan prestasi individual orang-orang dalam organisasi.
Brooks (2003) mengemukakan bahwa terdapat perspektif yang luas dalam organisasi, yaitu: (1) Model Populasi-ekologi menyarankan bahwa faktor lingkungan memilih karakter lingkungan organisasi yang paling baik dan sesuai untuk dilaksanakan. (2) Model Sumberdaya-bebas, menyarankan bahwa organisasi membuat keputusan dimediasi melalui konteks politis. (3) Model rasionalkontingensi menyarankan bahwa melalui sebuah kombinasi rasionalisasi dan kontingensi. (4) Model transaksi-biaya. (5) Model institusional.

Pandangan Makro terhadap sebuah organisasi lebih mudah di pahami melalui teori-teori organisasi, sedangkan pandangan mikro dapat dikenal melalui pendekatan perilaku organisasi. Sebagai organisasi, PT juga dapat dipahami melalui pendekatan baik secara makro, mikro dan melalui Lingkungan eksternalnya. Untuk mengkolaborasinya, ketiga pandangan tersebut dapat dipersempit dalam menganalisis perspektif dinamika organisasi. Sebuah organisasi yang sukses adalah sebuah organisasi yang efektip, yang dapat dinilai melalui produktivitas, kepuasan pelanggan, kualitas pekerjaan. Parson dan Etzioni (dalam Daft L.R dan Steers, 1986) mengatakan bahwa organisasi yang sukses adalah organisasi yang mampu mendapatkan dan menyediakan secara efisien, sumber daya untuk mencapai tujuannya. Dikatakan bahwa ujian tertinggi bagi manajemen yang baik adalah ketika mampu secara sukses mencapai tujuan organisasi melalui mengamankan dan menyediakan sumber-sumber dari lingkungan sekitar.

Organisasi yang dinamis, dapat diidentifikasi melalui model dalam bentuk blok bangunan 
organisasi (Daft L.R dan Steers, 1986) yaitu:

1. Individual dan Kelompok (Grup): Sebuah organisasi yang efektip apabila terdapat orang-orang yang memilki kemampuan, ketrampilan, dan motivasi yang tinggi, kelompok yang kohesif, norma-norma yang diakui kelompok, status sistem, dan proses peran. Karakter kerja kelompok mempengaruhi kerja individual, dan individual mempengaruhi performa kelompok.

2. Tugas-tugas dan Teknologi: Tugas adalah pekerjaan karyawan individual, dan teknologi mewakili kemampuan dasar menyeluruh, teknik-teknik dan mekanisasi yang dipergunakan organisasi secara keseluruhan. Desain pekerjaan secara signifikan mempengaruhi tidak hanya efisiensi dan efektivitas secara keseluruhan, akan tetapi juga perilaku dan sikap individu dalam bekerja.

3. Desain Organisasi: bagaimana manajemen membuat struktur organisasi yang efektip, bagaimana mengakomodasi teknologi, dan bagaimana manajer meletakan bersama desain blok bangunan organisasi.

4. Manajemen: yaitu blok bangunan organisasi yang bertanggung jawab mengatur dan mengkoordinasi seluruh bagian organisasi, melalui setting pencapaian tujuan organisasi dan mendefinisikan strategi-strateginya, mendesain organisasi, koordinasi, resolusi konflik, bertanggungjawab agar organisasi berjalan.

5. Proses Pengelolaan: kepemimpinan, pembuatan keputusan, kekuatan dan politik, konflik, komunikasi dan kontrol, perubahan dan inovasi adalah merupakan bagian dari proses pengelolaan. Mereka menjadikan organisasi hidup, berfungsi.

6. Lingkungan Eksternal: adalah komponen akhir dalam studi tentang organisasi. Organisasi adalah sebuah sistem, sehingga harus mampu beradaptasi untuk mencapai tujuannya.

Tatanan makro: berfokus pada unit analisis yang lebih luas, khususnya dalam keseluruhan organisasi sebagai suatu unit (struktur, orang sebagai satu kelompok, teknologi dan lingkungan). Dimensi organisasi, terdiri dari : dimensi kontekstual : ukuran organisasi ; teknologi yang dianut, lingkungan dan dimensi struktural : formalisasi dokumen ; kompleksitas ; rentang kendali ; sentralisasi ; profesionalisme ; konfigurasi staf (rasio ketenagaan). Kaitannya dengan membangun nilai kompetitif organisasi seperti PT, halhal yang perlu diperhatikan adalah :

1. Akreditasi Organisasi, menekankan pada mutu dan akuntabilitas publik institusi perguruan tinggi dan program studi, mengingat Undangundang RI Nomor 20 Tahun 2003, PP RI Nomor 19 tahun 2005 dan peraturan perundangundangan lainnya serta kecenderungan perkembangan kebijakan tentang pendidikan tinggi.

2. Penguatan kelembagaan, antara lain dengan menyiapkan arah dan komitmen keunggulan kelembagaan. PT berusaha menjadi dirinya organisasi pendidikan dengan ciri khas (brand image) misalnya: WCU (World Class University), Learning University, yang memiliki ciri khas atau akan berusaha keras mendidik manusia untuk menjadikan para alumninya dikenal sebagaimana yang diinginkan sesuai image 
PT itu sendiri. Menjadikan PT sebagai WCU merupakan sebuah usaha keras untuk meneguhkan PT sebagai lembaga berkualitas, menghasilkan devisa dan secara filosofis menjadikan masyarakat (lulusannya) menjadi cepat tanggap dan mampu menyesuaikan diri terhadap perubahan dunia yang begitu cepat (Huda, 2009)

3. Teknologi ICT, Learning Resources Center (LRC) : menjadi suatu keharusan bahwa Teknologi ICT sudah merambah kawasan pendidikan, tersedianya layanan terpadu Broadband internet dengan kapasitas besar, hot spot area di kampus, selain menjadi ikon ketertarikan calon pelanggan (mahasiswa), juga menjadi keharusan untuk sebuah organisasi pendidikan yang maju. Learning Resources Center berupa perpustakaan web based yang nyaman, tenang serta luas, dengan link yang luas, kenyamanan belajar dengan berbasis ICT, akses untuk jurnal, referensi asing maupun lokal yang tidak terbatas dengan koleksi lengkap, Laboratorium, dan kelengkapan pusat belajar lainnya. Selain itu juga teknologi organisasi yaitu Teknologi organisasi adalah dasar dari subsistem produksi, termasuk teknik dan cara yang digunakan untuk mengubah input organisasi menjadi output, dalam hal layanan kepegawaian, administrasi, sertifikasi, penyediaan web untuk universitas, marketing dan layanan ICT lainnya.

4. Efek dari luas sempitnya ruang lingkup sebuah organisasi. Ukuran adalah besarnya suatu organisasi yang terlihat dari jumlah orang dalam organisasi tersebut, berkaitan dengan efisiensi dan efektivitas, struktur, gaya dan type kepemimpinan, serta bentuk pengelolaan organisasi.

Tatanan mikro: difokuskan pada masalah-masalah dan isu-isu yang dihadapi oleh perseorangan/individual dan kelompok atau grup kecil di dalam sebuah organisasi. Hal yang terkait di dalamnya adalah pembawaan seseorang, motif dan kebutuhan, proses belajar. Pembawaan seseorang dapat dibagi dalam beberapa hal yaitu : Gaya kognitif, stabilitas emosional, kemandirian, sentivitas sosial, kecenderungan akan kekuasaan, dan gaya interpersonal. Kebutuhan individual adalah fiksasi berkelanjutan atau berulang pada beberapa tujuan khusus. Murray (Daft L.R dan Steers, 1986) mengemukakan kebutuhan Individu terdiri dari 12 buah (1 lusin) kebutuhan, yaitu : kebutuhan berprestasi : mengatasi hambatan, menjalankan kekuasaan, melakukan sesuatu sebaik dan secepat mungkin ; kebutuhan berafiliasi : membentuk pertemanan dan perkumpulan, menyambut, bergabung dan menjalani kebersamaan dengan orang lain, untuk bekerjasama dan hubungan sosial, untuk mengasihi dan untuk bergabung dalam kelompok ; Kebutuhan untuk Kekuasaan : untuk mempengaruhi orang lain, untuk membujuk, melarang, mendikte, untuk memimpin dan mengatur, untuk mengorganisir sikap kelompok.

Berkaitan dengan tatanan Mikro, untuk membangun nilai kompetitif pada organisasi pendidikan seperti $\mathrm{PT}$, hal-hal yang patut menjadi perhatian adalah :
1. Peningkatan
kemampuan
Manajerial dan Leadership.
Pemimpin pendidikan yang
berkualitas menurut Arcaro 
(1995,13), bahwa a quality leader is defined as a person who measures his or her success by the success of the individuals within the organization.
Pengertian tersebut menyiratkan bahwa pemimpin merupakan faktor yang sangat menentukan bagi kualitas organisasi, seperti yang digambarkan dalampiramida kepemimpinan berkualitas sebagai berikut.

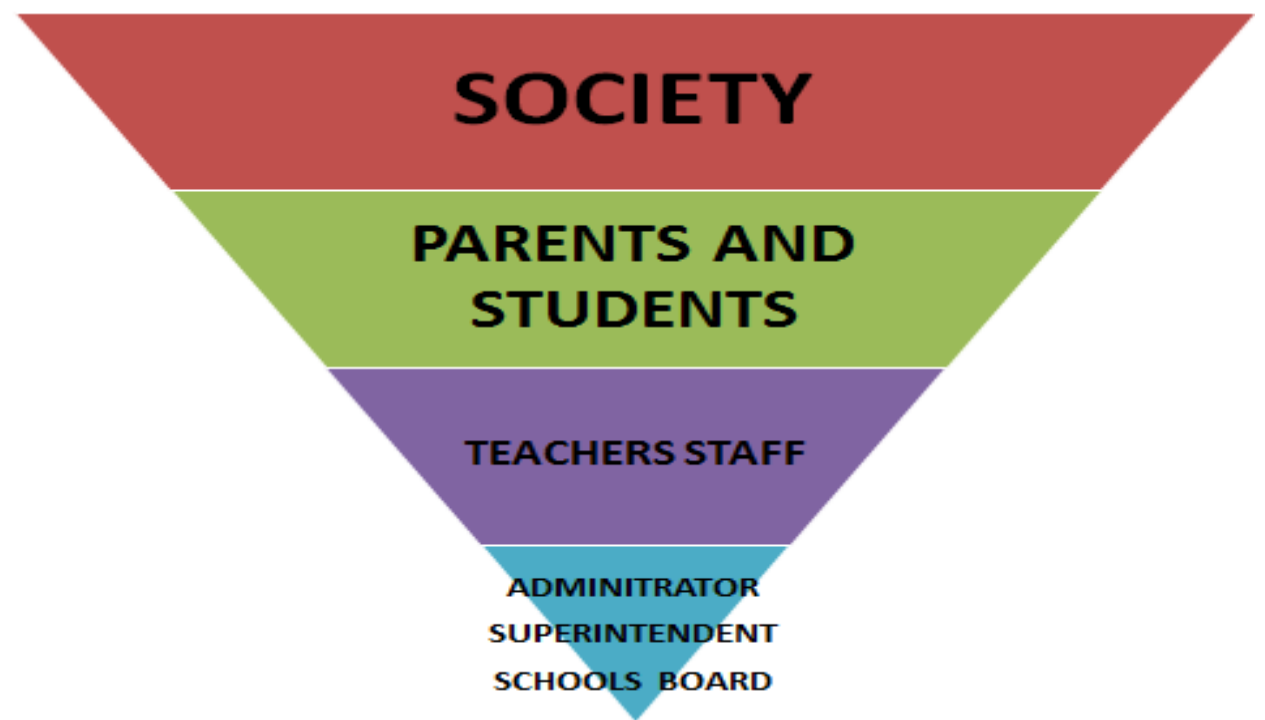

Gambar 1. Quality Leadership Pyramid

Arcaro

mengemukakan

(1995,17-22)

tentang

berbagaikriteria yang mendasari kualitas suatu organisasi pendidikan denganmengacu pada Malcolm Baldrige National Quality Award, the award criteria are built upon the core values and concepts of:

1) Berorientasi pada Konsumen (Customerdriven quality relationships with students, parents, and the community).

2) Kepemimpinan (Leadership)

3) Peningkatan Berkelanjutan (Continuous improvement : enhance the value of education to students through the development of new educational services, reduce inconsistencies that place the credibility of educational processes in question, improve responsiveness to student requirements, improve productivity and effectiveness in the use of all resources).

4) Partisipasi Total (Total participation)

5) Bereaksi cepat (Fast response)

6) Menggambarkan Kualitas dan Kesiapan (Design quality and prevention)

7) Berorientasi kedepan (Long-range outlook)

8) Pengelolaan Kejujuran (Management by fact : student performance, staff attitudes, educational program performance, operations, benchmarking, supplier performance, cost and financial analysis)

9) Pengembangan kemitraan (Partnership development)

10) Tanggung jawab terhadap masyarakat (Community responsibility) 
Dengan kepemimpinan yang tergambarkan di atas maka kualitas sebuah organisasi pendidikan dapat diandalkan untuk menjadi sebuah organisasi pembelajaran yang maju dan modern.

2. Motivasi dan prestasi melalui: Riset lembaga, pengabdian masyarakat. Berdasarkan hasil penelitian McClelland, Murray, Miller dan Gordon, disimpulkan bahwa ada hubungan yang positif antara motivasi berprestasi dan pencapaian prestasi. Artinya manajer yang mempunyai motivasi berprestasi tinggi cenderung memiliki prestasi kerja yang tinggi, dan sebaliknya jika mereka yang prestasi kerjanya rendah dimungkinkan karena motivasi berprestasi yang rendah (Anwar P.M.,2004). Selain itu kegiatan pengabdian masyarakat, merupakan karya pengabdian yang akan menambah kualitas civitas akademika untuk secara langsung menggali dan mempraktekan keilmuannya dengan baik, disamping memberikan sumbangsih kepada masyarakat secara nyata.

3. Pengembangan profesionalitas Dosen dan tenaga pendidikan: isu-isu kompetensi dosen, linieritas keilmuan, kemampuan penelitian dan inovasi-inovasi serta hal lain menyangkut profesionalitas dan kemampuan / kompetensi yang semakin tinggi tuntutannya. Sebagai tenaga edukatif, dosen memiliki peran yang sangat menentukan dalam melaksanakan tri dharma perguruan tinggi. Di sisi lain, dosen juga berperan sebagai pembina kurikulum, pengontrol peraturan-peraturan akademik, pencipta iklim pembelajaran mahasiswa, sosok yang mempengaruhi lingkungan intelektual dan sosial kehidupan di kampus dan dosen merupakan orang yang paling tahu proses nyata pelaksanaan pendidikan di kampus (Sonhadji, 1990)

Lingkungan Eksternal Perguruan Tinggi untuk membangun nilai kompetitif, hal-hal yang patut menjadi perhatian adalah:

1. Hubungan PT dengan dunia luar, masyarakat, akademik. Kerjasama dengan PT di luar negeri atau PT di dalam negeri baik dalam hal pembinaan dosen maupun kerjasama untuk kelas paralel, sandwich atau kerjasama teknis pendidikan lainnya, riset bersama, kuliah pakar, fellow lecturer. Kerjasama dengan industri juga merupakan langkah yang sangat baik untuk meningkatkan kualitas sebuah PT. Kerjasama PT dengan masyarakat dalam hal pemanfaatan sarana yang ada serta untuk riset dan pengembangan, misalnya sarana Laboratorium.

Peningkatan sarana Laboratorium dapat dilakukan dengan manajemen Laboratorium, sebagai pendayagunaan sumber daya secara efisien untuk mencapai tujuan laboratorium sebagai tempat latihan-latihan dan menghasilkan temuan-temuan (Sonhadji, 2003). Di harapkan Laboratorium menjadi tempat untuk menghasilkan produkproduk unggulan yang dapat di manfaatkan seluas-luasnya bagi masyarakat, pengembangan keilmuan, rekayasa dan sebagainya.

2. Lingkungan persaingan, dan lingkungan pasar (market). Gambaran terhadap keberhasilan dan daya serap alumnus memasuki lapangan 
kerja adalah merupakan sebuah evaluasi eksternal yang sangat penting. Untuk itu dilakukan Trace Study akan keberadaan atau sebaran alumni, seberapa besar life skill alumnus bermanfaat dalam dunia kerja, dalam pengembangan serta inovasi keilmuan di masyarakat. PT juga menjadi sarana pengembangan keilmuan baru yang diperlukan dimasyarakat, dengan pengembangan program studi berkualitas yang merupakan demand di masyarakat.

Evaluasi-diri merupakan upaya PT untuk mengetahui gambaran mengenai kinerja dan keadaan dirinya melalui pengkajian dan analisis yang dilakukan oleh PT sendiri berkenaan dengan kekuatan, kelemahan, peluang, tantangan, kendala, bahkan ancaman. Pengkajian dan analisis itu dapat dilaksanakan dengan memanfaatkan pakar sejawat dari luar PT, sehingga evaluasi-diri dapat dilaksanakan secara objektif.

\section{PENUTUP}

Konsep learning organization adalah organisasi yang melakukanpembelajaran secara sungguh-sungguh dan secara kolektif, danselanjutnya merubah dirinya untuk mengumpulkan, mengelola danmenggunakan pengetahuannya dengan baik untuk kesuksesanorganisasi. Komponenkomponen yang terlibat dalam system learning organization modelmencakuplearning, organizaton, knowledge, technology, danpeople.

Peran dan fungsi PT sebagai organisasi pembelajaran, di era Globalisasi seperti saat sekarang ini menjadikan organisasi ini sebagai wadah dan lembaga strategis dalam membangun komponen bangsa dan negara.PT juga sebagai organisasi ilmiah dan akademik penyelenggara pendidikan dan pengajaran yang selalu dituntut meningkatkan kualitasnya secara terus menerus.Dalam tatanan makro organisasi lebih mudah di pahami melalui teori-teori organisasi, sementaratatanan mikro dapat dikenal melalui pendekatan perilaku organisasi. Aspek makro organisasi berfokus pada unit analisis yang lebih luas, khususnya dalam keseluruhan organisasi sebagai suatu unit (struktur, orang sebagai satu kelompok, teknologi dan lingkungan),sementara aspek mikro organisasi umumnya difokuskan pada masalah-masalah dan isu-isu yang dihadapi oleh perseorangan/individual dan kelompok atau grup kecil di dalam sebuah organisasi yang difokuskan pada kepemimpinan, motivasi dan prestasi individual orang-orang dalam organisasi.

Perguruan Tinggi wajib untuk melakukan berbagai langkah pengembangan seluruh aspek. Pada tatanan makrodilakukan melalui: (1) pemantapan kualitas dan akreditasi organisasi perguruan tinggi;(2) penguatan kelembagaan melalui penciptaan brand image PT yang dapat dicapai; dan (3)pemantapan dan transformasiteknologi ICT pada berbagai aspek misalnya LRC, administrasi, penguatan laboratorium, web site, memperluas jangkauan broad band internet dan proses pembelajaran. Pada tatanan mikro,di lingkungan internal dilakukan melalui: (1) peningkatan kemampuan management dan leadership melalui pelatihan teknis; (2) program pelatihan yang terprogram guna menyiapkan generasi pemimpin PT yang handal; (3)memperkuat riset dosen dan mahasiswa; (4) memperkuat jurnal ilmiah, konferensi ilmiah,serta iklim kompetisi Riset bersaing;(5) pengabdian masyarakat; dan (6) pengembangan profesional dosen 
melalui pelatihan dan pendidikan berkelanjutan.

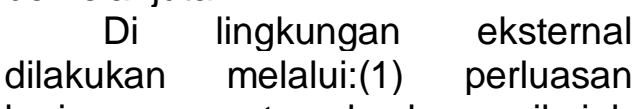
kerjasama antar lembaga ilmiah maupun PT, baik di dalam maupun luar negeri yang berkualitas untuk transformasi teknologi dan ilmu pengetahuan; (2)perluasan kerjasama dengan dunia industri dan badan-badan riset; dan (3) serta mempersiapkan mahasiswa untuk dapat terjun di masyarakat dan siap kerja.

Berbagai kegiatan tersebut merupakan bagian kegiatan untuk meningkatkan kualitas PTsebagai organisasi pendidikan menjadi semakin kompetitifdalam menghadapi persaingan global. Semuanya harus dilakukan melalui strategi cerdas dengan berbagai konsep dan implementasi teori organisasi pembelajaran.

\section{DAFTAR RUJUKAN}

Argrys, $C$ and Schon,D.A.1978. Organizatio nal Learning: A Theory of Action Prespective.

Philippines: Addisson-Wesley Publishing Company, Inc.

Anwar Prabu Mangkunegara. 2004.Manajemen Sumber Daya Manusia Perusahaan. Bandung: PT Remaja Rosdakarya

Arcaro, Jerome S. 1995. Quality in Education: An Implementation Handbook.St Lucie Press, Delray beach, Florida.

Barnard, I, Chester. 1992. Organisasi dan manajemen, Struktur, Perilaku dan Proses. Jakarta: Gramedia.

Daft L.R and Steers.M.R. 1986. Organizations: A Micro Macro Approach. England: Foresman and Company.

Brooks, I. 2003.Organisational Behaviour, Individual,
Groups and Organisation. $2^{\text {nd }}$ Edition. Harlow, England: Prentice Hall.

Hanson, E. Mark. 1997. Education Administration And Organizational Behavior. Third Edition. Boston: Allyn And Bacon

Huda, M.,2009, Menuju Universitas Kelas Dunia (World Class University).Pidato

Pengukuhan Guru Besar Bidang IImu Manajemen Pendidikan pada Fakultas IImu Pendidikan (FIP) Universitas Negeri Malang, Tanggal 20 Agustus 2009 di Malang: UM

Mantja, W. 2010.Profesionalisme Tenaga Kependidikan, Manajemen Pendidikan dan Supervisi Pengajaran, Kumpulan Karya Tulis Terpublikasi.Malang: Elang Mas.

Marquardt, Michael J. 1996. Building the Learning Organization, $A$ System Approach to Quantum Improvement and Global Success. New York: McGraw Hill.

Effendi,S.2003.

Pengelolaan Perguruan Tinggi Menghadapi Tantangan Global, Dipresentasikan pada Seminar Nasional Majelis Rektor Indonesia di Makassar, 31Januari - 2 Februari 2003

Rice, H.G and Bishoprick W.D.1971.Conceptual

Models of Organization, US:Appleton-Century CroftMeredith Coorp.

Senge, Peter M. 1990. The Fifth Discipline: The Art and Practice of The Learning Organization. New York: Doubleday.

Sallis, E. 1993. Total Quality Management In Education. London: Kogan Page 
Education Management Series.

Sonhadji, A. 2002. Laboratorium sebagai Basis Pendidikan Teknik di Perguruan Tinggi, Pidato Pengukuhan Guru Besar Bidang IImu Manajemen Pendidikan dan Pelatihan Teknik Universitas Negeri

Malang,Tanggal24

September2002 di Malang:UM

Sonhadji, A. 1990. Dosen Dalam Pengembangan Institusi.Makalah Disajikan pada Kursus Singkat bagi Tenaga Fungsional Akademi/Perguruan

TinggiTanggal : $: 30$ Juni 1990 di Semarang:Dirjen Dikti Depdikbud

Wahab, A.A. 2006. Anatomi Organisasi dan Kepemimpinan Pendidikan, Telaah terhadap Organisasi dan Pengelolaan Organisasi Pendidikan, Bandung: Sekolah Pasca Sarjana UPI dan CV.Alfabeta

Yukl, G. 1994. Kepemimpinan dalam Organisasi, Leadership in Organizations 3e, Edisi Bahasa Indonesia, Alih Bahasa : Jusuf Udaya, Jakarta: Prenhallindo

Sumber on line

http://epaper1.kompas.com/k ompas/books/151216kompas /\#/3/ (diakses 30 Oktober 2016) 